\title{
Improving the Ability of Teachers in Developing Student Character Based on Local Culture
}

\author{
Pebrian Tarmizi ${ }^{*}$ and Osa Juarsa
}

\author{
University of Bengkulu, Bengkulu, 38371, Indonesia \\ *Corresponding author. Email: tarmizifebrian28@gmail.com
}

\begin{abstract}
The problem of community service that is carried out is "How to increase the ability of teachers to develop national character based on local culture? The aim is to develop the teacher's ability to explore and instill local cultural character values, so that it is expected to reduce the degradation of moral values among students. The schools targeted at SDN 46 in Benteng district and surrounding schools with 26 teachers. The training is carried out using the methods of lectures, demonstrations, questions and answers and displaying material through power point media depicting the lives of teenagers in particular and the negative behavior of the Indonesian nation that leads to the degradation of moral values and how to explore the value of wisdom, an increase in the ability of teachers to explore and apply them in RPP within the educational unit. The evaluation technique is by means of oral and written tests which are carried out during the training process, after the activity ends and conduct visitations, observations, and assistance to several schools that help the successful implementation of the training results. The results of the activity indicated a significant increase in the participants' understanding. Participants can explore the moral values of children's character based on local culture in their environment properly and correctly, as well as understanding the types of moral character values based on local culture that are nurtured to children in the school environment, they are also able to plan learning activities that support the understanding of the values of local character and culture.
\end{abstract}

Keywords: Student character, local culture, moral values.

\section{INTRODUCTION}

The occurrence of public concern is due to a crisis of moral character carried out by teenagers through various unsympathetic behaviors such as brawls between schools / villages, fights between teenagers, cohabiting, motorbike racing on the road, disobeying and molesting their parents, skipping school, drinking, and rape and many other negative behaviors. The cause of this case may be due to various factors, including peer group association, the influence of mass media (film, TV, and pornography), community environment, family environment, and the loss of ideal figures or figures. One of the reasons for these reasons is thought to come from the efforts of educators who have not presented situations and conditions that children can feel and live with as happiness. So that children are not yet able to dialogue and are called to learn to have and develop moral character. Therefore, formal education is thought to be one of the causes of the low moral character of children.

The impact of science and technology on character change also occurs in Indonesia, such as broadcast by the media, both TV and newspapers, many incidents of student brawl, underage sexual behavior, irresponsibility, indiscipline, short-term thinking, reduced prosocial spirit, selfishness, loss of awareness and a willingness to participate socially, the development of corrupt behavior at almost all levels, violence on the streets that are difficult to cultivate, inter-ethnic conflicts, anarchist, aggressive demonstrations, even murders over the issue of one thousand rupiah currency, murder rape and so on. Seeing this phenomenon, many of those who think that currently the Indonesian nation is in a sick condition that requires proper treatment and treatment through providing character education for all levels of educational units [1].

Nowadays, the tendency to solve problems by force and cases of coercion often appears in Indonesia. This tendency also affects the younger generation, for example in cases of mass fights. Although there has been no scientific study that violence originates from the curriculum, several education experts and community leaders state that one of the root problems is the implementation of a curriculum that emphasizes the cognitive aspects and support of students in their learning room with activities that are less challenging for students in their learning room. with activities that are less challenging for students. Therefore, the curriculum needs to be oriented and reorganized 
towards the learning load and learning activities that can answer this need.

Various cases related to abuse of authority, manipulation, including the existence of fraud in the National Examination show the urgency of efforts to cultivate a culture of honesty and anti-corruption through learning activities in educational units. So, the curriculum must be able to become a guide in characterizing the character values of honesty in students. This is very concerning for cultural observers and educators in Indonesia. Therefore, in 2010 the Ministry of National Education held workshops and seminars. The results of the study concluded that national value education is a necessity.

Character value education is loving the school environment and can help students develop good attitudes, for example ethics and responsibility through modeling and teaching character through character values that exist in the environment [2]. Character education based on local culture is expected to provide solutions in dealing with moral degradation among adolescents in particular and the nation in general. Local culture-based character education is a development from the previous curriculum to respond to various internal and external challenges. Curriculum development is very necessary because it is in line with the advancement of science, technology and arts and culture of society as well as changes in society in the local, national, regional and global order in the future. These various changes have created internal and external changes in the field of education.

Thus, character value education based on local culture should be designed for the purpose of creating communities with the ability to interact as individuals and citizens who are faithful, accountable, innovative, creative, affective and care for the environment and are able to contribute to society and civilization in the world. The curriculum is an educational tool to bring people to have the appropriate knowledge, attitudes and skills so that they can become orderly students and citizens.

Based on thoughts about the direction, goals and objectives of education Local culture-based character values as an innovation in the field of education, the education unit is obliged to carry out comprehensive local culture-based character value education for various activities including the management of character education. by teachers at the educational unit level. The application of national character education at the school level by teachers based on local culture-based character education is one solution in solving the degradation of moral values / character among students, by that character it is necessary to socialize and improve the managerial ability of teachers in implementing managerial character education in education-based education character based on local culture.

\section{METHODS}

To carry out these community service activities, carried out by training, visitation and mentoring methods on the implementation of national character education management by teachers in various local culture-based education units. This training and mentoring activity begins with giving a verbal pretest to the participants about understanding the vision and mission, the types of moral values implanted, methods and models of value education and how to evaluate moral values that are believed and obeyed by students. Based on the results of the pretest, materials / materials for counseling and training were prepared.

Sukmadinata [3] argues that qualitative research views a phenomenon based on the perspective of participants or people who are invited to interview, interview, data, and others. Therefore, this study is based on participants as a source of research data to conduct data research, analyze and conclude the results based on the data obtained.

Qualitative research views data as it is based on what is found in the field, so researchers must be able to find data in accordance with what is shown by participants. This was explained by Sugiyono [4] that qualitative researchers are required to be able to explore data based on what was said, felt, and done by participants or data sources. This means that the data found by researchers in the field are not exaggerated or reduced. This method is used to get a picture of a current situation as stated by Zuriah [5] states that "descriptive research is research that is directed to provide symptoms, facts, events systematically and accurately regarding the characteristics certain population or area".

Training and mentoring are carried out using lectures, demonstrations, question and answer methods and displaying material through power point media as well as pictures of various lives of teenagers in particular as well as negative Indonesian behavior leading to degradation of moral values. The participants were given many opportunities to share their experiences and various problems experienced in fostering children's moral values in their respective educational units. Assistance is specifically carried out for the participants in exploring local cultural wisdom which is used as a source and basis for developing character values that will be instilled in students. As a post-test, the participants were given the opportunity to answer questions posed by the instructor to find out an increase in their understanding of the material that had been discussed.

Visits to schools will be carried out after training and mentoring activities are carried out. Visitation is carried out to monitor the implementation of character value education on local cultural content in elementary schools and to provide solutions to various obstacles experienced in the field (Table 1). Visitation also serves as an evaluation material for the program implementation of this activity.

Evaluation of activities is carried out to see an increase in the ability of teachers to explore and implement national character education management in 
the local culture-based education unit. The evaluation technique is by:

a. Oral and written tests that were carried out at the beginning of the activity, the training process took place after the activity ended.

b. Conducting visitations and assistance to several schools that have problems implementing character education management so that they can help the successful implementation of training results.

Table 1. Activities to explore and implement national character education management

\begin{tabular}{|c|l|l|l|}
\hline No & Instructor & $\begin{array}{l}\text { Training, } \\
\text { mentoring and } \\
\text { visitation } \\
\text { materials }\end{array}$ & $\begin{array}{c}\text { Execution } \\
\text { time }\end{array}$ \\
\hline 1 & $\begin{array}{l}\text { Dr. Osa } \\
\text { Juarsa, } \\
\text { M.Pd }\end{array}$ & $\begin{array}{l}\text { Background, } \\
\text { scope, and } \\
\text { values of } \\
\text { national } \\
\text { character } \\
\text { education }\end{array}$ & $\begin{array}{l}\text { August 26, } \\
2019\end{array}$ \\
\hline 2 & $\begin{array}{l}\text { Pebrian } \\
\text { Tarmizi, } \\
\text { M.Pd }\end{array}$ & $\begin{array}{l}\text { Exploring } \\
\text { character values } \\
\text { based on local } \\
\text { cultural } \\
\text { excellence }\end{array}$ & $\begin{array}{l}\text { August 27, } \\
2019\end{array}$ \\
\hline 3 & $\begin{array}{l}\text { Dr. Osa } \\
\text { Juarsa, } \\
\text { M.Pd }\end{array}$ & $\begin{array}{l}\text { Compilation of } \\
\text { character } \\
\text { education in } \\
\text { local culture for } \\
\text { learning tools } \\
\text { Pebrian } \\
\text { M.Pd }\end{array}$ & $\begin{array}{l}\text { August 28, } \\
2019\end{array}$ \\
\hline
\end{tabular}

\section{RESULTS}

In particular, this community service activity has the aim of developing the ability of teachers to explore the values of local cultural characters and to improve teachers in developing local culture-based characters in students into learning tools. In line with these objectives, the implementation of this PPM will enable teachers to have the ability to explore and develop character values based on local culture to students. So that it is expected to inhibit the degradation of moral values among students.

In order to achieve these targets, the activity targets were the teachers at SDN 46 Bengkulu Tengah. This activity is designed in two stages, consisting of the first stage of providing counseling and training to increase understanding, the insight of teachers in fostering the moral values of children's character based on local culture in the educational unit and the second stage holding visitation and mentoring to teachers who have difficulty in develop local culture-based characters in students into learning tools.
The second stage of activity was carried out by conducting visits to training participant education units who continued to communicate with instructors on September 2 and 3 2019. The visits were made to educational units that had difficulty realizing training materials and in transmitting material to other nearby educational units. The visits to the education unit were carried out to monitor activities and provide solutions to the obstacles experienced by teachers.

The results of the tests carried out during the training showed a lack of understanding of the participants in exploring the values of character based on local culture. Types of character values in local culture that are fostered to children in the school environment, compile plans of learning activities that support the inculcation of character values. Participants generally only understand that character education is the responsibility of teachers in the field of PKN, Religion and Social Studies and the implementation of coaching is integrated in learning activities only.

The training activities took place warmly and actively because the participants were very enthusiastic to participate. The dialogue strategy created for the delivery of material is felt to be very appropriate to the existing conditions because participants as educators do not feel "taught", as a problem in instilling a local culture-based character that is felt so far can be presented and found scientific solutions and does not cause saturation.

After completing the training activities, a verbal post test was held not to find out if there was an increase in the understanding and insight of the participants in exploring local culture-based character values in the education unit. The post-test results showed a very significant increase in understanding. Participants better understand in exploring the moral values of children's character based on local culture in their environment properly and correctly, types of characters in local culture instilled in children in the school environment, planning learning activities that support the inculcation of cultural character values with local cultural character values.

Based on the description of the training results, there is an increase in understanding and broad insight in exploring the character of the culture in the environment properly and correctly, the types of moral values in the culture in the local environment that are fostered for children in the elementary school environment, compiling plans for learning activities that support the cultivation of values on local culture. To see the implementation of the participants' understanding and insights, the community service team communicates through social media and continues to monitor it to help solve the problems they are experiencing. The results were very encouraging because the participants gave very positive responses.

\section{DISCUSSION}

Character education has a close relationship with value education, where value is one of the substances of 
human character. Value is the result of determination or as a quality project which can involve all states of appreciation or willingness/interest. Meaning: "value is a determination, or a quality object that concerns all kinds of appreciation or interest". Meanwhile Mulyana [6] defines value as belief in making choices. As for value education as part of character education is an educational program that is organized systematically and programmatically to foster essential meanings in humans. Thus, humans (students) can appreciate the essence of the material they receive, not just capturing information.

Based on research conducted by Chairiyah with the research title Implementation of Character Values through Local Wisdom at Taman Siswa Jetis Yogyakarta Elementary School. The results showed that character education based on local wisdom, apart from being manifested in the form of extracurricular subjects and activities, the content of local wisdom values can also be interpreted in every subject, in every learning process and in the implementation of learning [7].

The application of character value education through local culture can create the quality of education, improve the morality of the nation, and can improve the quality of implementation and educational outcomes in schools, such as character and noble character of the community. students as a whole so become human. In addition, by instilling character values through local culture in students, they are not only intellectually intelligent, but also emotionally and spiritually intelligent.

At first, the character education program at the state elementary school 46 Bengkulu Tengah seemed separated from its parent. Character education programs are considered special subjects (special matter) that intersect with religion, social, philosophy, or humanities. In fact, the value as part of the character iscore (the core) of each subject matter, and values must be able to color all components, environments, programs or school activities. This is in line with the Islamic concept that is kaffah, universal, and is a blessing for the life of the world (rahmatan lilalamin).

Local culture-based character education at SDN 46 Bengkulu Tengah has the aim of making students become whole humans, perfect humans (insan kamil) by not forgetting local values but in line with religious values. The achievement of perfection is shown by the formation of a person who has al-Karimah character. A person with character is a person who has the ability to manage his life in accordance with values (both divine and human). Such ability exists in personal strength in carrying out the tazkiyat al-nafs activities through riyadhah and mujahada so that value internalization occurs. All efforts that aim to develop personalities must be directed so that students have sensitivity and appreciation of values.

Character education does not merely place the value system as material for consultation in formulating educational goals, but also becomes a reference in educational systems and strategies. At the operational level, character education needs to be implemented in new (innovative) formats, although not always formal and curricular in nature. Character is not only limited to encouraging intellectual work in using attitudes, or desires to meet needs. Far from it, character functions to guide and nurture humans to have noble character and be able to find their own existence to realize the true purpose of life.

Education and learning strategies based on character, values, morals and norms based on local culture at SDN 46 Bengkulu Tengah, must be designed in an integrated manner with education and other learning based on local culture. It cannot stand alone as a subject. Besides that, the success of character-based education / learning is more determined by the learning strategy in the sense of how students construct information into their characters into their brains and thoughts which are then internalized to themselves.

Character education in integrated learning with all local culture-based subjects, the means of integration are subject matter, delivery procedures, and the meaning of students' learning experiences. As a consequence of integrated learning, the student's learning mode must vary according to the character of each student. Variations in learning can be in the form of reading reference materials, making observations, conducting experiments, interviewing sources, and so on in a group / individual way.

The implementation of variations in student learning modes needs to be supported by variations in the modes of delivery of lessons by the teachers. The habit of delivering exclusive lessons and expository approaches should be developed into more diverse approaches such as discussion and inquiry. Activities to convey information, strengthen concepts, express students' experiences through monologues by the teacher need to be replaced with a mode of delivery which is marked by active involvement of students both intellectually (meaningfully) and emotionally (its usefulness is lived out) so that it is more responsive to efforts to realize the full goals of the program education by not leaving local cultural values but in line with the religious values they adhere to.

\section{CONCLUSION}

The conclusion from this community service activity is that there is an increase in the understanding and insight of the participants / teachers in exploring local culture-based character values in educational units, this is indicated by the ability to: The type of value base based on local culture that is developed for students is basically derived from the religious values they adhere to, the ideological values of the state and the cultural values that apply in society. Of the three value foundations, religious values have a very strategic position and are the basis for other values. Therefore, delivery takes precedence. Having skills in planning learning activities that support the inculcation of local culture-based character values. Increased understanding and insight of these participants can be implemented 
properly within the educational unit as well as socialized to the nearest education unit environment so that it will have a wider impact.

\section{SUGGESTION}

The results of this study suggest:

a. The activity of providing understanding and adding insight into the application of the local culture-based education model needs to be carried out more thoroughly to various regions / places considering the symptoms of degradation of moral values among adolescents are now very pronounced.

b. It needs support from all parties, especially local governments, in order to include a character education development program based on local culture in the agenda of their government, so that it is hoped that it can reduce the level of juvenile delinquency which has recently been very disturbing for the community.

\section{ACKNOWLEDGMENTS}

The implementer of the activity is grateful to the Community Service program, based on a research contract financed through PPKP funds FKIP Bengkulu University for Fiscal Year 2019 contract number 2562 / UN30.7 / HK / 2019 contract date May 21, 2019 which has facilitated the implementation of this activity so that it can run well.

\section{REFERENCES}

[1] Mulyasa, E. Competency Standards and Teacher Certification. Bandung: Youth Rosda karya, 2007.

[2] Berkowitz, MW \& Bier, MC. What Works In Character Education: A Re-search-Driven Guide for Educators, Washington DC: Univesity of Missouri-St Louis, 2005.

[3] Sukmadinata, Nana Syaodih. Educational Research Methods. Bandung: PT Remaja Rosda karya 2016.

[4] Sugiyono. Understanding Qualitative Research. Bandung: Alfabeta, 2012.

[5] Zuriah, Nurul. Moral Education \& Character in a Change Perspective. Bumi Aksara, 2007.

[6] Mulyana, Rohmat. Articulating Value Education, Bandung: Alfabeta, 2004.

[7] Chairiyah. Implementation of Character Education through the Values of Local Wisdom at Taman Siswa Jetis Yogyakarta. Journal of Elementary Education, 2017, September Vol. 4, Number 1, p. 208-215. 